\title{
Joonistatud dokumendid
}

Kadri Viires

\begin{abstract}
Teesid
Inimkultuuris dokumenteeritakse ümbritsevat maailma. Etnograafilise dokumenteerimise eriliik on joonistatud dokumendid. Kuni fotograafia leiutamiseni 1839. aastal oli joonistamine ainus esemete pildilise kujutamise võimalus. Üheks esimeseks kirjeldustega varustatud dokumenteerivaks jooniseks võib pidada August Wilhelm Hupeli teose Topographische Nachrichten von Lief- und Ehstland II osas (1777) avaldatud Carl Magnus Lilienfeldi gravüüri "Eesti rõivad Põltsamaalt". Aastatel 1920-1922 pandi alus Eesti Rahva Muuseumi käsikirjalisele etnograafilisele arhiivile ja etnograafiliste jooniste kogule. Etnograafiliste jooniste valmistamine oli alguses seotud professionaalsete kunstnike kaastööga, hiljem sai sellest kunstiüliõpilaste etnograafiapraktika osa. Joonisel on erinevalt fotograafiast jm vahenditest võimalik tuua esile olulisim, edastada erijooni, tekstuuri jne.
\end{abstract}

Märksõnad: dokumenteerimine, Eesti Rahva Muuseum, etnograafiapraktika, etnograafiline joonis, joonistatud dokumendid

Inimkultuurile on üldiselt omane vajadus salvestada enese ümber ja keskel asetleidvaid protsesse, dokumenteerida ümbritsevat esemelist ja vaimset keskkonda nii kirjas, helis kui ka pildis. Salvestamiseks kasutavad erinevad meediumid erinevaid vahendeid ja meetodeid. Visuaalses vormis ümbritsevad tänapäeva inimest kõige igapäevasemalt mitmesugused dokumenteerivad salvestised filmi- ja fotodokumentalistika vallast; nende võidukäik on olnud seotud tehniliste vahendite kiire arengu ja kättesaadavusega. Laialt on levinud ettekujutus nende võimest jäädvustada ümbritsevat maailma "täiuslikult ja erapooletult", sest valguskiire abil tundlikule alusmaterjalile joonistatud "tõelise" kujutise teket ei ole vahendanud inimkäsi. Foto- ja filmidokumentide eel ja kõrval on kasutusel aga ka teisi visuaalse informatsiooni dokumenteerimise viise, mis sisaldavad endas võimalusi nii info talletamiseks kui ka analüüsiks.

Rääkides etnograafilise materjali dokumenteerimisest, on teoreetilist käsitlemist leidnud eelkõige visuaalantropoloogiline foto-, video- ja kinematograafia, analüüsitud on nende rolli uurimisvahendina, nende visuaalset keelt ja kujundeid, esteetikat, dokumenteerimisvõimet, staatust jne (Margaret Mead, John jun. \& Malcom Collier, Jon Prosser, Elizabeth Edwards, Howard Becker, Marcus Banks jpt). Käelise tegevuse tulemusel tekkinud jäädvustusest, sh

http://haldjas.folklore.eeltagused/nr29/viires.pdf 


\section{Kadri Viires}

joonistusest, ning nende visuaalses kujundis sisalduvast informatsioonist saab rääkida võrdluses "tehnograafiliste" jäädvustustega, mida on teinud semiootik Göran Sonesson oma artiklis "Chirography", lõpetades tõdemusega, et seda valdkonda pole siiski piisavalt uuritud või kui, siis traditsioonilises kunstiteaduslikus võtmes.

Eraldi etnograafiliste joonistuste kui joonistatud dokumentide teoreetilisi käsitlusi pole mul õnnestunud leida, sest ilmselt jääb see valdkond välja nii kunstiteadlaste (kuivõrd need ei ole kunstiteosed) kui ka etnoloogide (kuivõrd need on kunstiteosed) vaateväljast. Küll aga leidsin üksikud artiklid Eesti Rahva Muuseumi joonistekogu rajamisest (vt Peterson 1984), kunstnike ja üliõpilaste osalemisest kogumisaktsioonides kogujate-dokumenteerijatena (vt Sild 1972; Astel 1984; Linnus 1984), üleskutseid joonistuste tegemiseks (vt Viidalepp 1938), joonistuste põhjal tehtud uurimustest (vt Voolmaa 1959) ja Esticast joonistustel etnoloogi (vt Manninen 1932) ja kunstiteadlase (vt Allikvee 1994) positsioonidelt, milles kõigis rõhutatakse joonistuste vajalikkust ja tähtsust nii esemelise kui ka vaimse kultuuri dokumenteerimisel.

Kuni tähelepanuväärse 1839. aastani, mida peetakse fotograafia ametlikuks sünniaastaks, oli pildilise informatsiooni talletamine ja edastamine paratamatult seotud eelkõige joonistusoskusega. Kõrvuti kunstilise, väljendusliku-interpreteeriva pildiloomega oli aktuaalne ka teine, dokumenteeriv-jäljendav-illustreeriv käsitluslaad, mille puhul polnud eesmärgiks mitte uue kunstnikuvisiooni loomine, vaid uuritava materjali võimalikult adekvaatne jäädvustamine vastandina lavastuslikule või väljamõeldule. Dokumenteerivad joonistused leidsid rakendust eelkõige teaduslikke uurimusi ja reisikirju illustreeriva materjalina. Joonistama õppisid nii ajaloolased, arheoloogid, geograafid, botaanikud kui ka anatoomid, et teha oma uuringutest ülestähendusi, joonistusoskus oli osa tolleaegsest haridusest. Peamiselt oli tegemist pliiatsi- või tušijoonistustega, kuid rakendati ka professionaalsete kunstnike ja trükimeistrite abi tööde lõplikul vormistamisel ja graafikatehnikatesse viimisel (peamiselt puu-ja vaselõige ning litograafia), mis oli vajalik piltide trükiväljaannetes reprodutseerimiseks.

Üldiselt on jäänud dokumenteerivad joonistused tänu oma rakenduslikule iseloomule väljapoole moodsaid kunstivoolusid, kuid neis on jälgitavad oma ajastu kunstitehnilised võtted ja uurimisvaldkondade huvikeskmed.

Järgnevalt püüan vaadelda vaid neid dokumenteerivaid joonistusi, mis käsitlevad eesti etnograafilist ainest. Alltoodu ei pretendeeri 
ammendavale ülevaatele sellealasest materjalist üldse, mis võiks olla eraldi uurimisteema. Eriti varase pildimaterjali puhul on kunstiteose ja dokumentaalse illustratsiooni piirjooned hajusad, neid mainitakse allikmaterjalina nii kunstiteaduslikes kui ka etnoloogilistes uurimustes. Erinevas kontekstis käsitletakse üksikuid varaseid, 16.-17. sajandi eesti ainest kujutavaid pilte -1577 . aastal avaldatud (vt Manninen 1932) illustratsioone Liivimaa rahvariietest, mille seas on oletatav eesti rahvariietes neiu, ja Adam Oleariuse aastatel 1633-1639 läbitud Venemaa teekonna reisikirja illustratsioone nii etnograafiliste algdokumentide (Manninen 1932) kui ka kunstiteostena:

Eestlastega otseselt seotud ainestik leiab tee kunsti juba 17. sajandi reisikirjade vahendusel (Allikvee 1994).

Alljärgnevaid 18. sajandist pärinevaid pilte Anu Allikvee kunsti kontekstis enam ei märgi, küll aga mainib neid etnograafiliste dokumentidena Ilmari Manninen. Seoses uurijate üleüldise suurenenud huviga erinevate rahvaste ja kultuuride vastu leidub eesti rahvarõivaste kui rahvakunsti kõige dekoratiivsema osa pildilisi kirjeldusi mõningates Venemaa või "kõiki maailma rahvaid" käsitlevates teostes. Üheks esimeseks kirjeldustega varustatud dokumenteerivaks jooniseks rahvarõivais eestlastest võib pidada August Wilhelm Hupeli teose Topographische Nachrichten von Lief- und Ehstland 2. osas (1777) avaldatud Carl Magnus Lilienfeldi gravüüri "Eesti rõivad Põltsamaalt".

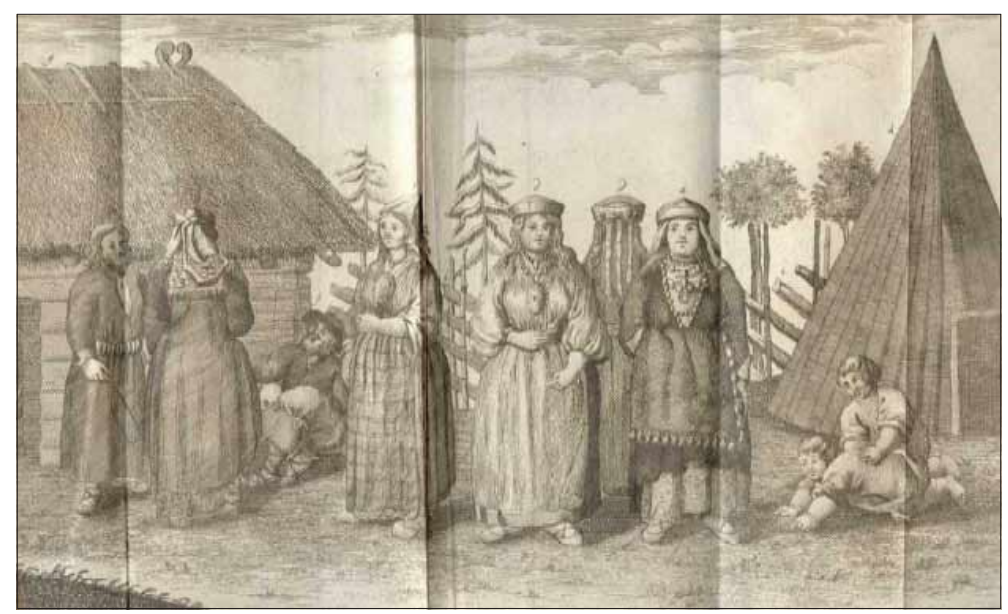

Joonis 1. Carl Magnus Lilienfeld. "Eesti rõivad Põltsamaalt” (Hupel 1777). 


\section{Kadri Viires}

Tuntuimad ja korduvalt reprodutseeritud on saksa päritolu vene uurimisreisija ja etnograafi Johann Gottlieb Georgi (1729-1802) teoses Vene impeeriumi rahvustest Description de toutes les nations de l'empire de Russie (1776-1780) avaldatud kolm koloreeritud vasegravüüri eesti rahvarõivais naisefiguurist. Koguteos sisaldab eri trükkides 73-100 illustratsiooni erinevate rahvaste rahvariietes esindajatest. Larissa Petina (1998) märgib ajakirjas Raamatukogu avaldatud artiklis "Estonica J. G. Georgi etnograafilises töös", et vastupidiselt tavalisele praktikale sündiski J. G. Georgi raamat piltidest, mitte tekstist. Esialgu trükiti Sankt-Peterburgis kunstnik Carl Rothi gravüürid, mis olid teostatud Peterburi Teaduste Akadeemia Kunstikambri materjalide, ekspeditsioonist osavõtnute joonistuste ja elusate modellide järgi. Pildid anti välja ka eraldi vihikutena ajakirja kujul, millele hiljem lisandus selgitav tekst. Ka I. Manninen oletas, et tegemist võis olla kattuvate piltidega (Manninen 1931).

Baltisaksa kultuuriloolase Johann Christoph Brotze monumentaalses 10-köitelises joonistuste ja käsikirjade kogus "Sammlung Verschiedener Liefländischen Monumente, Prospecte, Münzen, Wappen etc." leidub rohkete originaalillustratsioonide seas mõningaid akvarelliga koloreeritud eesti kostüümide ning talupojastseenide joonistusi (nt "Liivimaa talupoja pulm»), aga ka pilte taluhooneist, näiteks "Eesti talu Pärnu lähistel”, mida tuleb hinnata eelkõige etnograafilisest aspektist.

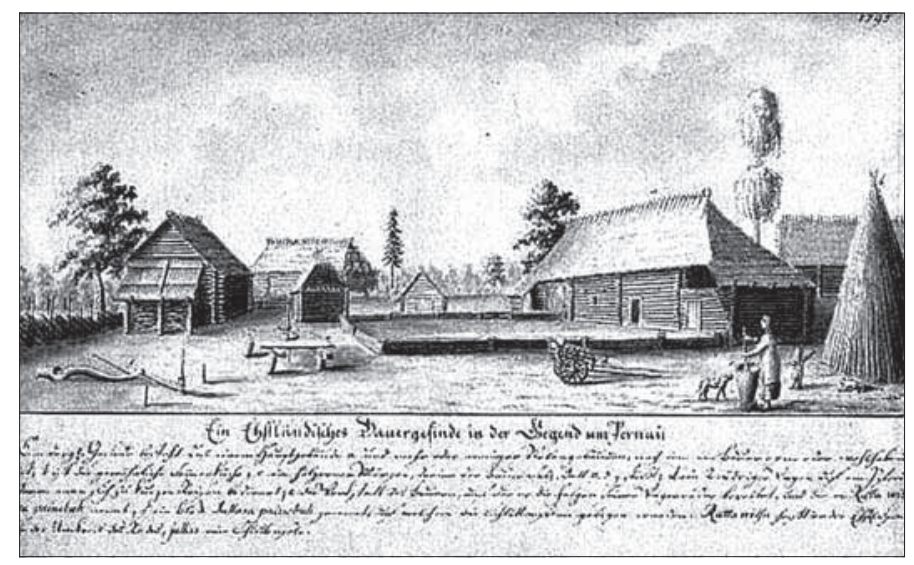

Joonis 2. Johann Christoph Brotze. "Eesti talu Pärnu lähistel”. 1795. 

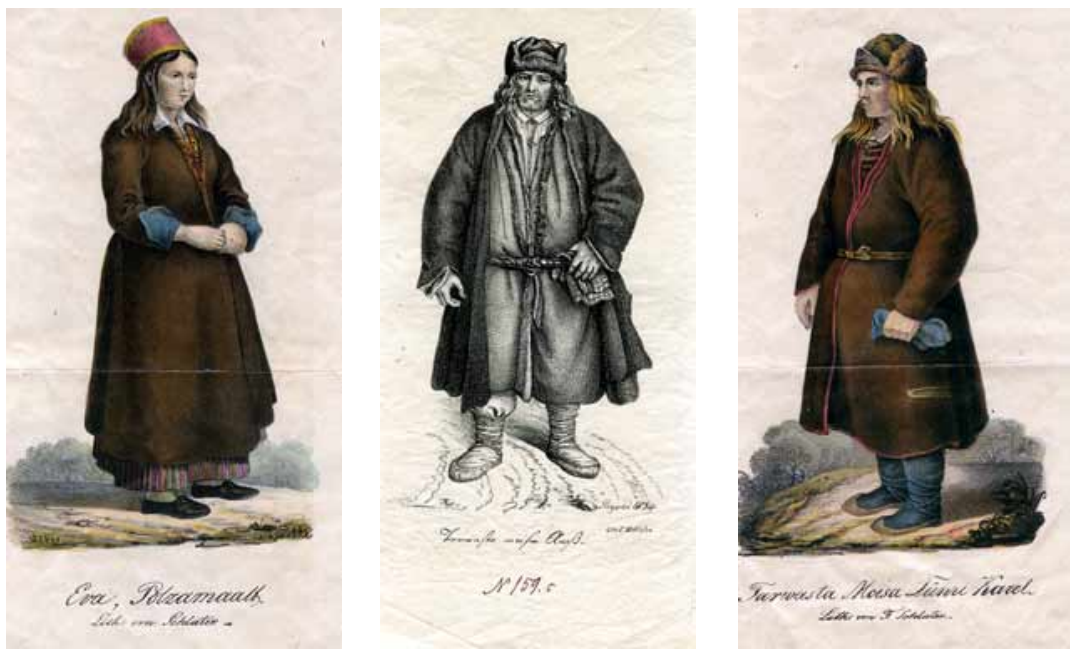

Joonis 3. August Georg Wilhelm Pezold. "Ewa Põlzamalt", "Tarwasto moisa Anss" ja "Tarwasto moisa Türni Karel”. 19. sajandi teine veerand. Värvilised litograafiad.

Huvi rahvusliku ainese kujutamise ja jäädvustamise vastu on olnud suuresti sõltuvuses ajastu üldistest arengutest ning suhtumistest, mis omakorda kajastuvad ka pildilise materjali rõhuasetustes ja valikutes. Rahvuslik teema tõuseb kujutamise huviorbiiti romantismi lainel 19. sajandi teisel veerandil baltisaksa kunstnike loomingulis-interpreteerivates pildikäsitlustes, milles võetakse vaatluse alla kohalik, mitte rahvuskaaslaste, vaid eesti talupojakultuur. Kunstnikuks, kes tõi Estica teema baltisaksa kunsti ning oli selle teema viljakaimaks ja mitmekülgseimaks meistriks, nimetab A. Allikvee August Georg Wilhelm Pezoldit, kellelt pärineb rida Eesti-ainelisi teoseid, mille seas on ka populaarsed Georg Friedrich Schlateri trükikojas litografeeritud joonistused “Tarwasto moisa Anss" (6 EKM G 4516, ERM EJ 79: 15), “Tarwasto moisa Tünri Karel” (ERM EJ 79: 14) ja "Ewa Põlzamalt" (EKM G 4517, ERM EJ 79: 5), ning mida on rohkesti ekspluateeritud just etnograafilises kontekstis. Tuntud on ka Friedrich Ludwig von Maydelli, Hermann Eduard Hartmanni (ERM EJ 79: 26-27), Ernst Hermann Schlichtingi (SU 554: 1-8), Theodor Gehlhaari (ERM EJ 147) ja G. W. Hirschauseni (ERM EJ 79: 29) tööd, mis haakuvad nende aastate etnograafiahuviga ja võtavad vaatluse alla ka talupoegade kombestiku kujutamise. Et romantilise talupo- 


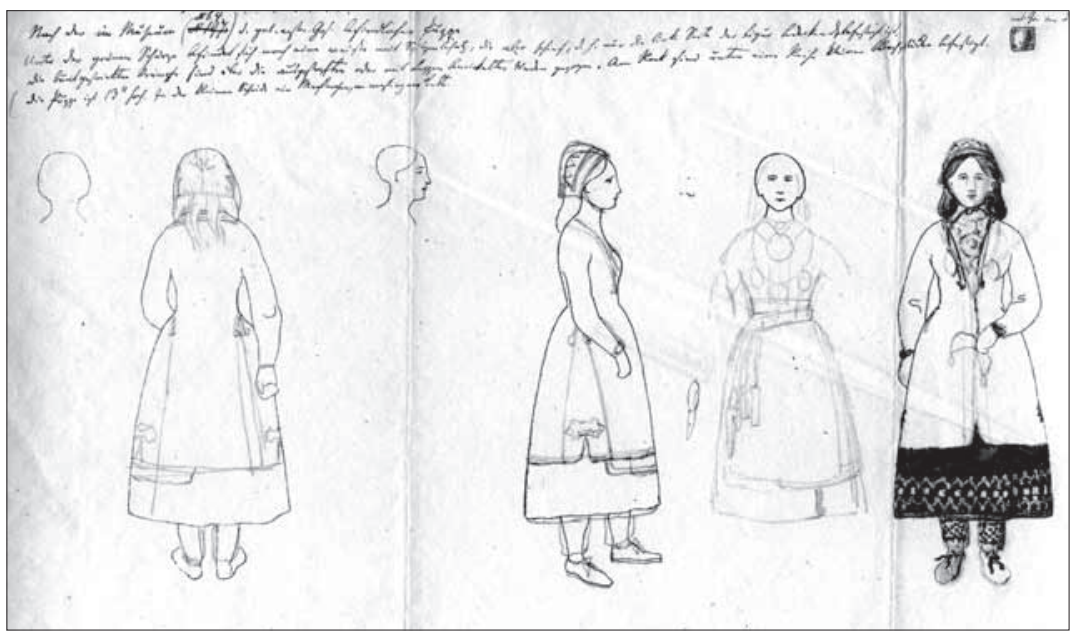

Joonis 4. Hermann Eduard Hartmanni joonistused. 19. sajandi teine veerand.

jateema kujutamise järele on olnud nõudmine, kinnitavad nimetatud kunstnike gravüüride mitmed järeltrükid ja asjaarmastajate nende järgi tehtud koopiad (nt M. Platonoff E. H. Schlichtingi järgi SU 207:1-6 jpt).

Süsteemsema joonistekoguga paistab teiste baltisaksa kunstnike seas silma Saaremaal kreiskooli õpetajana tegutsenud Friedrich Sigismund Stern (1812-1889), kelle kultuurilooliselt tähtsaim loominguline pärand koosneb 20 Saaremaa kaheteistkümne kihelkonna rahvarõivaid kujutavast koloreeritud litograafilisest lehest, mis on loodud ajavahemikus 1856-1871 (ERM EJ 148: 1-20). Need on postkaardisuurused kompositsioonilt lavastuslikud litograafiad, mille eesmärk on olnud rahvarõivastest etnograafilises-illustratiivses laadis tõepärase pildi andmine. Kõnealune materjal on loodud loominguliste graafikalehtede sarjana, millele ei ole lisatud täpsustavaid etnograafilisi kirjeldusi ega jooniseid.

Esimese etnograafiliste dokumenteerivate joonistena kogumisaktsiooni käivitas Õpetatud Eesti Selts (ÕES) 1842. aasta aprillis, saates kõigisse kihelkondadesse pastoritele ja teistele maal elavatele haritlastele trükitud üleskutse koos küsimustikuga eesti rahvarõivaste joonistamiseks ja kirjeldamiseks. Sellele üleskutsele oli lisatud neli litograafiatehnikas trükitud lehte figuurikontuuridega rahvarõivaste ja peakatete joonistamiseks. Alusjoonised valmistas 
ÕESile kingituseks baltisaksa kunstnik Friedrich Ludwig von Maydell paar aastat varem. Kuigi üleskutse leidis tagasihoidlikku vastukaja (selle aktsiooni tulemusena on Eesti Rahva Muuseumi (ERM) joonistekogus 12 joonistelehte ERM EJ 79: 112), on laekunud materjalide hulgas huvipakkuv Friedrich Reinhold Kreutzwaldi käsikiri Alutaguse rahvarõivaist (ERM EAV 7) ja joonised (ERM EJ 79: 1-4), mida on pikemalt analüüsinud Aino Voolmaa (Voolmaa 1959). F. L. v. Maydelli litografeeritud figuuride ja peakatete alusjoonised soovitavad rõivastuse kirjeldamist nii eest-, tagant- kui ka külgvaates, kuid kontuurjoonised on väikesemõõdulised ning võimaldavad joonistamist vaid kõige üldisemas



Joonis 5. Friedrich Sigismund Stern. Anseküla mees. 19. sajandi keskpaik.

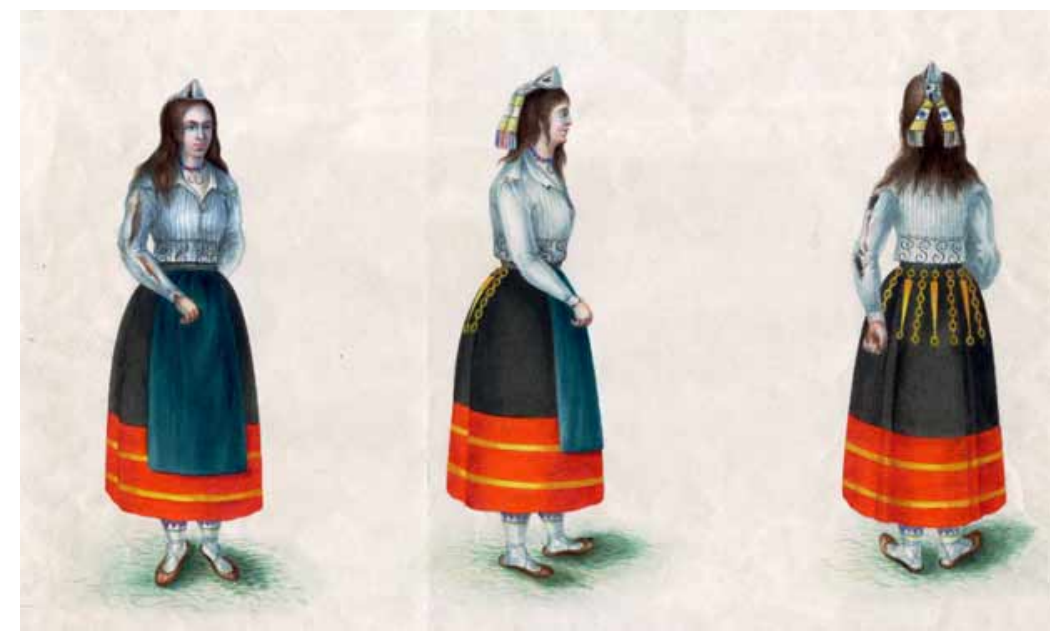

Joonis 6. Friedrich Reinhold Kreutzwaldi joonistus Alutaguse rahvarõivastes (ERM EJ 79: 1)t. 


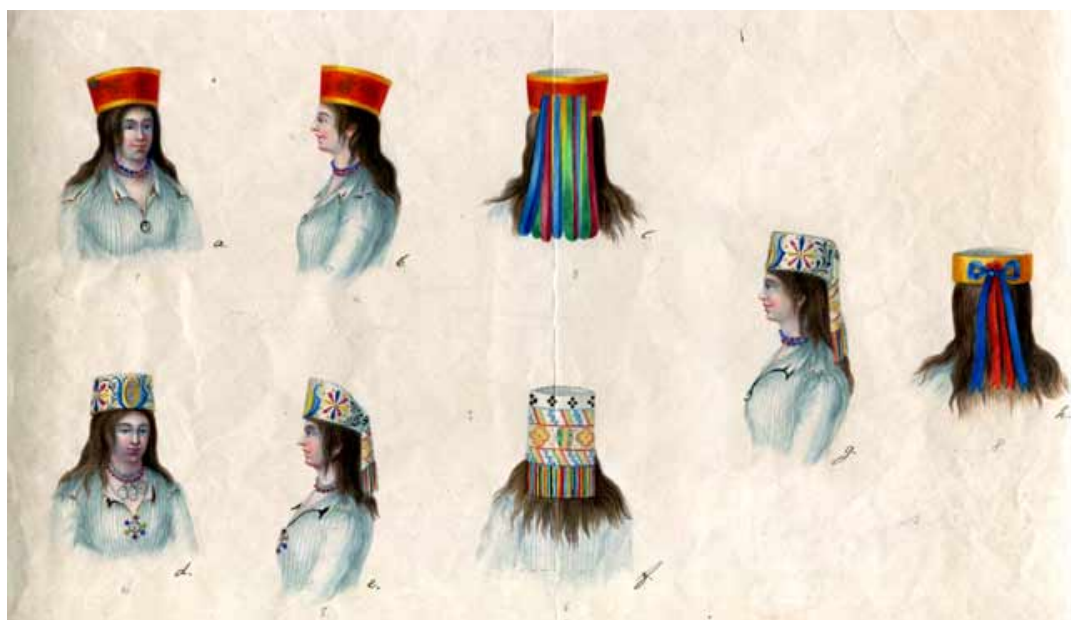

Joonis 7. Friedrich Reinhold Kreutzwaldi joonised Alutaguse naiste peakatetest (ERM EJ 79: 4).

plaanis ilma detailide ja lõigeteta. Joonistusaktsioon andis S. Sternile ja E. H. Schlichtingile tõuke rõivaste ja peakatete kujutamiseks.

Ülaltoodud joonised on leidnud kasutamist nii etnograafiliste, eriti rahvarõivaalaste väljaannete illustreerimisel kui olnud ka uurimuste alus- või võrdlusmaterjaliks, olenemata nende piltide loomise taustast ja eesmärgist.

Teaduslikuks otstarbeks tehtud dokumenteeriva etnograafilise joonistuse, nagu ka eesti ainese teaduslikku literatuuri viimisel on oluline roll Soome etnograafia ühel rajajal Axel Olai Heikelil (18511924), kes oma uurimis- ja kogumisreisidel, sh Eestisse tegi ka jooniseid, pöörates peatähelepanu taluehitiste ja rõivastuse uurimisele. 1885. aasta pikemal uurimisreisil saatis teda joonistaja S. von Bell. A. O. Heikeli huvikeskmes olid taluhoonete ehitustüübid, millest ta

[---] laskis oma sehkendajal mitu pilti maalida, mida ta pea maailmale ilmutada tahab (Viires 1980).

Samas märgitakse, et Ridala kihelkonnast tõi A. O. Heikel kaasa ligi kolmkümmend ehitiste joonistust ja plaani. Et ehitiste kõrval pöörati tähelepanu ka teistele esemelise kultuuri valdkondadele, kinnitavad Carl Joseph Samuel von Belli joonistused Lihula sõlge- 
dest, noast ja adrast (SU 17:1-3). 1886. aastal kaasnes A. O. Heikeli magistrikraadi piduliku pühitsemisega etnograafiliste esemete ja joonistuste näitus Helsingis, kuhu peosüüdlane oli välja pannud umbes 700 Soome sugu rahvaste asja ja umbes 1000 pilti. Pole teada, kui palju nende seas oli ja mida täpselt kujutasid Eestit puudutavad joonised (vt Viires 1980). 1901. aastal tutvus A. O. Heikel Tartu muuseumi (Õpetatud Eesti Seltsi muuseumi) esemekoguga, tundes huvi eelkõige setu materjalide vastu. A. O. Heikelit reisil saatnud kunstiüliõpilane Juhana Wilhelm Mattila oli üles joonistanud eelkõige setu meeste- ja naisterõivaid, ornamente ja detaile, kuid joonistuste seas leidus esemeid ka Eesti teistest piirkondadest (SU 12:1-89). A. O. Heikel hindas Tartu muuseumi kogu olukorda äärmiselt viletsaks, märkides juba tollal tekstiilesemete tugevaid koikahjustusi, mistõttu pole võimatu, et mõned neist esemeist on tänaseni säilinud vaid J. V. Mattila joonistustel.

1901. aastal tegi A. O. Heikel kogumismatka Eesti saartele ja Läänemaale ning 1902. aastal Setumaale, Mulgimaale ja Kuramaale. Reiside tulemuseks oli nii eseme- kui jooniste- ja fotokogu täienemine. 1909. aastal ilmus tema rahvarõivakäsitlus Die Volkstrachten in den Ostseeprovinzen und in Setukesien, mille illustratiivne materjal põhineb olulises mahus joonistustel. Sellele väljaandele kunstnikupositsioonilt hinnangut andes on Ants Viirese andmetel märkinud Kristjan Raud:

Heikeli töö on sõna otseses mõttes teaduslik. Ülesande esteetilist külge pole ta sugugi puudutanud. Ja ometi on ehtivus ja iluküsimus riiete otstarbega lahutamata ühenduses ja vahest ta pääasigi (Viires 1980).

Võimalik, et A. O. Heikeli eeskujul võttis Eesti rahvusteaduste üks alustala, rahvaluule kogumise initsiaator Jakob Hurt oma 1903. aasta kogumisreisile Setumaale kaasa arstiteaduse üliõpilase Viktor Reieri, kellelt pärinevad väikeseformaadilised pliiatsijoonistused setude majapidamisesemetest, tööriistadest, liiklusvahenditest, hoonetest, ehetest, rõivastest jne (ERM EJ 501: 65). Kuigi joonistuste kunstitehniline tase on asjaarmastajalik, ilmneb neis dokumenteeriva esemejoonistuse iseloom. Materjali on kujutatud üksikesemete ja valdkondade kaupa, mis on välja toodud muust ümbritsevast keskkonnast. Mõnele joonisele on lisatud mõõtkava või täpsustav detailijoonis. Osa neist joonistest on avaldatud Jakob Hurda kogutu väljaandes Neli keelt "Vanast kandlest" (1989). 


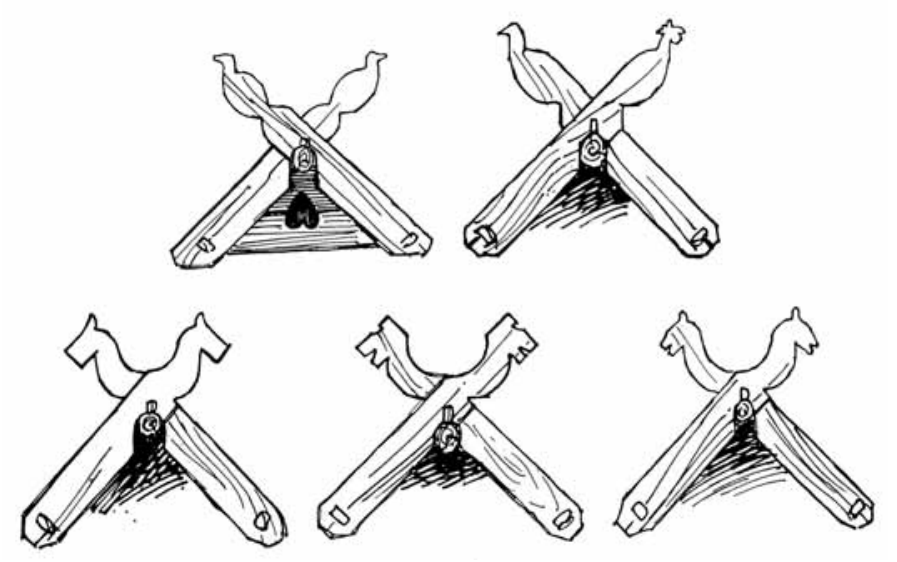

Joonis 8. Hans Werneri joonistus Ruhnu taluhoonete unkalauad.

Sajandi esimesel kümnendil jätkus ka baltisaksa kunstnike ja arhitektide huvi eesti etnograafilise materjali vastu. Saaremaalt pärit Peterburi arhitektide Johannes Gahlnbäcki ja Hans Werneri uurimuslikke artikleid eesti rahvakunstist ilmestavad meisterlikud joonised. J. Gahlnbäck lisas aastaraamatus Jahrbuch für Bildende Kunst in den Ostseeprovinzen IV ilmunud artiklile "Estnische Holzkrüge" nii fotosid kui ka mõõtkavaga varustatud joonistusi rahvuslikest dekoreeritud õllekannudest. Arhitekt H. Wernerilt ilmus 1909. aasta aastaraamatus joonistega rikkalikult illustreeritud artikkel Ruhnust (vt Werner 1909). Vaatluse all oli puitarhitektuur kirikust taluhooneteni, ehitiste puitkaunistused, hoonete sisustus ning tekstiilid.

Ühiskondlikest organisatsioonidest alguse saanud rahvusteadusliku ainese kogumine viis 19. sajandi II poolel Põhjamaades rahvusmuuseumide asutamiseni. Eestis jõuti selleni pikaajalise protsessi tulemusena alles 1909. aastal. Eesti Rahva Muuseumis (ERM) alanud ulatusliku ja plaanipärase kogumistöö üldiseks põhimõtteks oli saada võimalikult täieliku esemetekogu vahendusel ülevaade mineviku elust. Kõrvuti aktiviseerunud vanavarakogumisega, mis hõlmas kõiki rahvakultuuri valdkondi, laienes ka joonistusobjektide valik: kogumisreisidelt toodi kaasa joonistusi nii taluhoonetest, talupojamööblist kui vöö- ja kindakirjadest. Korjajaid, teiste seas kogumistööst aktiivselt osa võtnud kunstnikke ja kunstiüliõpilasi, lähe- 
tati kogumisretkedele paarikaupa, nii et üks paariline oli "kunstitundja”, kelle ülesandeks oli rahvakunstiesemete väljavalimine ja nende esemete joonistamine, mida kaasa ei antud. Korjajad pidid

[---] asjade kohta tegema võimalikult põhjalikke tähendusi ja kirjeldusi, samuti joonistusi ja päevapilte nendest asjadest, mida mitte ühes ei saa võtta, iseäranis hoonete välimusest, sisemusest, tubade sisseseadest, õuedest, mitteäraantavatest huvitavatest asjadest ja nende karakteristlikkudest detailidest kui ka inimeste ülikondadest (Sild 1972).

Eseme saamisel või joonistamisel tuli kirja panna selle vanus, kasutamine, valmistamine, päritolu jne. Tolleaegsed nõudmised kogutavale visuaalsele materjalile kehtivad põhimõtteliselt tänini, esitades dokumenteerivatele joonistustele tingimused formaadi ja mitmekülgse lisainformatsiooni osas. Etnograafilised joonistused muutusid osaks esemelise kultuuri süstemaatilisest talletamisest ning olid kooskõlas muuseumi kogumisprintsiipidega. Kunstnike rolli ERMi asutamisel ja kogumistöös käsitledes märgib Hilja Sild, et võrreldes kunstnike kogutud esemete arvuga 1910. ja 1920. aastail korraldatud vanavarakogumisaktsioonidel ( $c a 4000$ eset) on joonistuste osa siiski tagasihoidlik (230 lehte 636 üksikjoonisega). Ta põhjendab seda mittemotiveerivate töö-ja tasustustingimustega (Sild 1972).

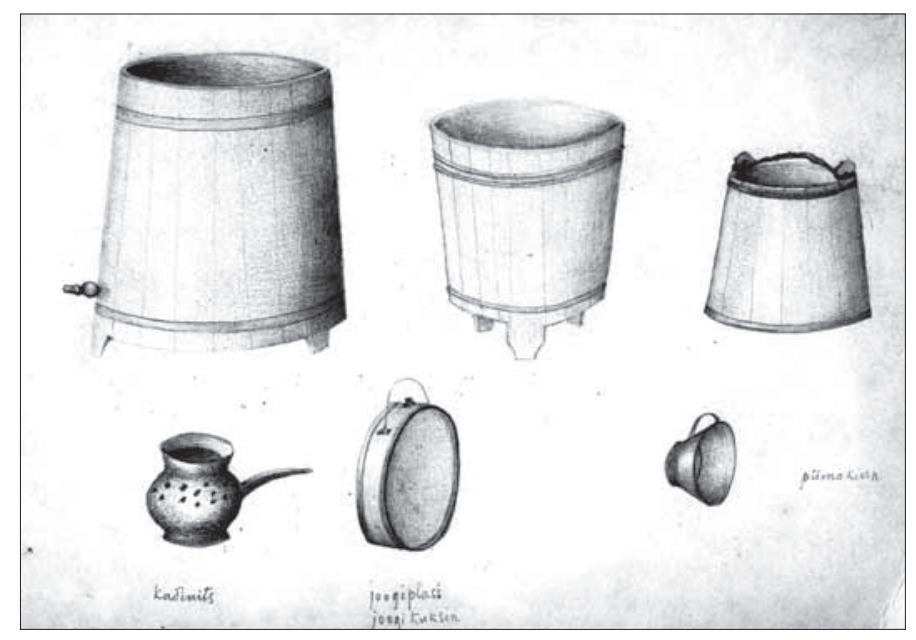

Joonis 9. Viktor Reier. Puunõud Setumaalt. 


\section{Kadri Viires}

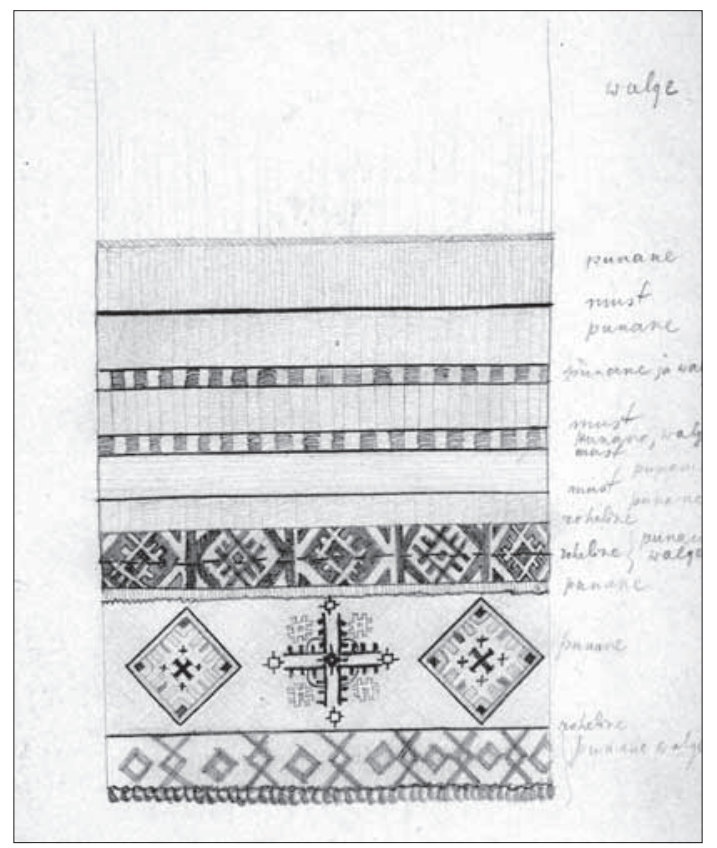

Joonis 10. Viktor Reier. Setu tikandid.

Aastatel 1920-1922 pandi alus Eesti Rahva Muuseumi käsikirjalisele etnograafilisele arhiivile ja etnograafiliste jooniste kogule. Etnograafiliste jooniste kogu loomine ja kasv on olnud algusest peale kõige tihedamalt seotud kunstirahvaga. Oma panuse sellesse on teiste seas andnud rida nimekaid eesti kunstnikke, nagu Nikolai Triik, Aleksander Uurits, August Pulst, Aleksander Tassa, Rasmus Kangropool, Johannes Võerahansu, Elmar Kits, Günther Reindorff, Esko Lepp jpt.

Esimeste seas registreeriti joonistekogusse kunstnik Voldemar Haasi ja arheoloogiaüliõpilase Richard Indreko taluehitisi kirjeldavad joonised juba 1921. aastal (ERM EJ 1: 1-30). Ulatuslikum rahvapärastele ehitistele keskendunud joonistamine-plaanistamine hoogustus 1923. aastal, mil koos ERMi direktori Ilmari Mannineniga töötas rida kunstnikke, arhitekte, kunsti- ja arhitektuuriüliõpilasi, tehes silmapaistvalt täpseid, korrektseid ja informatiivseid jooniseid. 1930. aastatel Gustav Ränga koostatud juhendi alusel jätkunud taluehitiste plaanistamistööde kõrval laekus joonistekogusse 
Kadri Viires



Joonis 11. Viktor Reier. Setu naistekasukas.

materjali ka majapidamisesemeist, tööriistadest, peremärkidest, ornamentidest, rõivastest, ehetest jne, kattes nii suure osa huvipakkuvaist rahvakultuuri valdkondadest.

Pärastsõjajärgne rahvusliku ainese kogumine ja talletamine joonistustena, aga ka selle interpreteerimine kunstiloomingus, mis oli eriti aktuaalne 1950.-1960. aastail tarbekunstis, on suures osas seotud kunstiõppeasutuste ja ERMi koostöö ning juhtivate kunstnike-õppejõudude ja nende poolt suunatavate üliõpilaste süvenemisega rahvakunstipärandisse. See tegevus kandis selget rahvusliku eneseväljenduse vaimu. Tekstiilikunstnik Mall Tomberg (Tomberg 2004) meenutab 1949. aasta Eesti Kunstiakadeemia (tollase ENSV Tallinna Riikliku Tarbekunsti Instituudi, TRTI) tootmispraktikat Sindi tekstiilivabrikus, kust professor Mari Adamsoni poolt juhendatud tekstiiliüliõpilased "kargasid" mitmeks nädalaks Kihnu saarele etnograafilist materjali koguma-joonistama-pildistama. Selle omaalgatusliku "praktika" tulemusena koostati põhjalik illustreeritud etnograafiline kokkuvõte Kihnu rahvakunstist. Tarbekunsti- 


\section{Kadri Viires}

erialade üliõpilaste ERMis läbi viidud etnograafiapraktika põhjal valmis ka mahukas suureformaadiline joonistustemapp, mis üliõpilaste omal initsiatiivil paljundamiseks litografeeriti ning koloreeriti (materjalid M. Tombergi erakogus).

1940. aastate lõpul alustati TRTIs (alates 1951. aastast Eesti Riiklik Kunstiinstituut, ERKI) etnograafiapraktikatega ka teistel erialadel, ühena esimestest puitehistöö (ruumi- ja mööblikujunduse, praeguse sisearhitektuuri) erialal. Sellest ajast pärineb rohkesti nii praktikate kui ka kunstiõppejõudude uurimustöö raames tehtud etnograafilisi joonistusi erinevatest rahvakunstivaldkondadest, mis enamasti on leidnud koha ERMi joonistekogus, osaliselt ka õppeasutuste erialastes või eraarhiivides. Kui ERMiga koostöös tehtud või sinna üle antud joonistused on süstematiseeritud ja lisaandmetega varustatud, siis õppeasutuste ja eravaldusesse jäänud jooniste suurimaks probleemiks on andmete puudulikkus, sest kogumisel ja arhiveerimisel ei pööratud piisavalt tähelepanu tööde dateerimisele ja lisainformatsiooniga varustamisele. Seetõttu on paljud meisterlikud joonistused-mõõdistused kaotanud dokumenteeriva väärtuse.

1957. aastal algatas ERM ulatusliku eesti taluehitiste uurimise, mis jätkus 1980. aastateni ja oli tingitud maapiirkondades kiiresti hävivate hoonetüüpide jäädvustamise vajadusest. Aktsioon põhines süstemaatilisel hoonete ja õueplaanide dokumenteerimisel jooniste-mõõdistuste ja fotodena. Dokumenteerimistöösse haarati peale muuseumitöötajate ka kunstnikke väljastpoolt, sh ERKIst. Kogumisaktsiooni juhtiv organiseerija, ERMi tolleaegne direktor Aleksei Peterson peab kõige suuremaks väärtuseks tehtud joonistuste süsteemsust ja järjepidevust, territoriaalselt kompleksselt jäädvustatud situatsioone ja väga täpselt paikapandud tööprintsiipe, mis teevad sellest joonistekogust unikaalse dokumendikogu ja uurimisallika. A. Peterson rõhutab joonistusoskuse ja mõõtmistehnika olulisust, mida tundsid kõige paremini arhitektuuriüliõpilased, kelle kõrval töötasid ka teiste erialade tudengid (Peterson 2004). Peale ehitiste tehti jooniseid veel elamusisustusest, majapidamisesemeist ja põllutööriistadest. Kokkuvõttena lisandus etnograafiliste jooniste kogusse 1634 lehte 2517 üksikjoonisena (Astel 1984).

1980. aastatel jätkus töö rahvusliku ainese kogumisel joonistustena muuseumi kunstnike poolt (Lembit Lepp, Annes Enehielm jt), kuid puudus initsiatiiv suuremate joonistusaktsioonide ellukutsumiseks, sest pidevalt täiustuv fototehnika oli ammugi muutunud 




Joonis 12. Hermann Eduard Hartmann. Ebajumalakuju.

uurijate kõige käepärasemaks tööriistaks nii esemete kui ka olustiku dokumenteerimisel, võimaldades kokku hoida aega ja tööjõudu. Nii jäid etnograafilised joonistused põhiliselt kunstierialade õppetöö osaks. Eriti silmapaistvad on nende seas Leila Pärtelpoja juhendamisel ERKI ruumikujunduse eriala üliõpilaste süsteemselt tehtud ajaloolise mööbli ja interjööri joonised, kuid oma panuse ERMi joonistekogusse on andnud ka Tartu Kunstikooli ja Tallinna Pedagoogikaülikooli õppurid.

1990. aastate kunstitudengite etnograafiapraktikate ja nende käigus tehtud joonistuste eesmärk on olnud pigem olemasolevate rahvakunstimaterjalidega tutvumine ja nende kogumine konkreetsete loominguliste ülesannete teostamiseks. Jätkuvalt on etnograafilised joonistused vahepeal Eesti Kunstiakadeemiaks (EKA) ümber nimetatud kunstikõrgkooli soome-ugri uurimisekspeditsioonide üheks oluliseks töövaldkonnaks, mis lisaks kodumaisele materjalile dokumenteerivad joonistepõhiselt ka teiste soome-ugri rahvaste esemelist kultuuri.

ERMi joonistekogu materjale (2001. aasta 1. jaanuari seisuga $c a$ 22000 joonistelehte) võib pidada unikaalseks rahvakultuuri dokumendikoguks, millel puuduvad otsesed analoogid teistes muuseumides. Ilmselt on joonistuste suur osa omamaise materjali dokumenteerimisel olnud seotud fotograafia suhtelise pretensiooniku- 


\section{Kadri Viires}

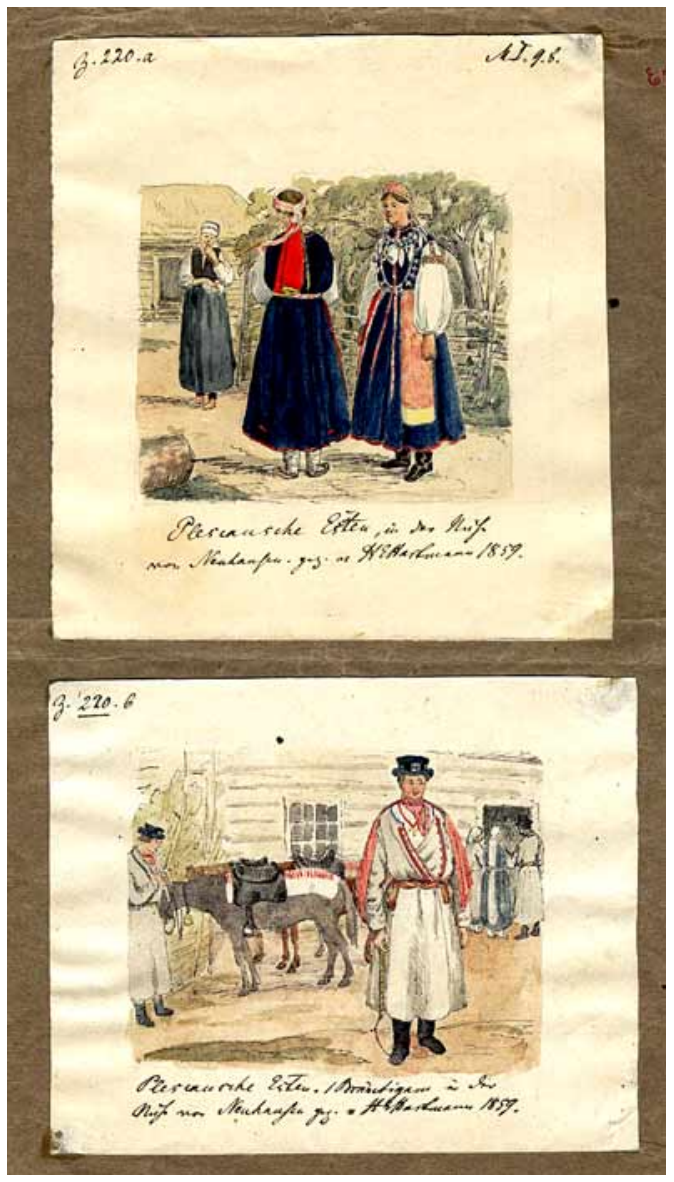

Joonis 13. Hermann Eduard Hartmann. Olustikupildid Setumaalt. 1859.

se, kalliduse ja piiratud tehniliste võimalustega (monokroomsus, tagasihoidlik trükikvaliteet, piiratud valgustundlikkus jne), seda hoolimata fotograafia jätkuvast võidukäigust alates selle ilmumisest Eestimaale juba 19. sajandi 40. aastatel (fotograafia on üldrahvalikuks harrastuseks muutunud alles 20. sajandi lõpuveerandil) ning kunstnikkonna aktiivse rolliga rahvusteadusliku materjali kogumisel-talletamisel.

Dokumenteerivad joonistused on nagu fotodki üks võimalik viis materjali visuaalseks kirjeldamiseks ja informatsiooni kogumiseks ning säilitamiseks, kasutades erialaspetsiifilisi vahendeid. Graafiliste vahendite abil on võimalik luua illusioon kolmemõõtmelisest ese- 
mest ning edasi anda väga erineva karakteriga materjale ja tekstuure - puitu, metalli, luud, nahka, tekstiili jne (erinevate materjalide karakteristikale ja nende graafilisele väljenduslikkusele pöörati erilist tähelepanu ERKI disainieriala etnograafiapraktikate raames). Kuid ka fotograafia puhul on tegemist kolmemõõtmelisuse illusiooniga tasapinnal, mis samuti sisaldab endas uurija subjektiivset nägemust ja on piiratud tehniliste võimalustega. Dokumenteerivate joonistuste eesmärk on talletada kompleksne pilt kujutatavast ehk uuritavast objektist ja kirjeldada seda võimalikult kõigi parameetrite järgi. Joonistuses tuuakse esile esemele kõige olulisem ja iseloomulikum, kusjuures lisajoonised võimaldavad anda lisateavet tehnoloogilistest iseärasustest (detailid, sõlmed, läbilõige, vaated).

Dokumenteerivateks joonistusteks tuleb pidada ka leppelisi tingmärke kasutavaid jooniseid, mille puhul pole esmatähtis kujutav, vaid joonistustehniline täpsus. Siia alla tuleks arvata arhitektuursed joonised, plaanid ja vaated, mille abil antakse edasi ehitiste ruumijaotust, asendit, ehituslikke konstruktsioone, sisustuse paiknemist jne. Sellist ülevaadet ei ole võimalik saavutada foto abil. Joonistuste juurde kuuluvad vältimatult mõotkava, mitmekülgseks kirjeldamiseks vajalikud lõiked, mustriskeemid, värvikaardid, mis on olnud aja jooksul vähem muutlikud kui värviline fotograafia, rääkimata tänapäevasest, hõlpsat manipuleerimist võimaldavast digitaaltehnoloogiast. Joonistuste kõrvutamisel on võimalik välja tuua piirkondlikke eripärasid ja koostada kartograafilisi ülevaateid.

Etnograafiline joonistus eeldab kujutatava alusmaterjali tehnoloogiliste iseärasuste ja valmistamise peensuste head tundmist. Siin peitub ka seos arheoloogiliste materjalide dokumenteerimise ja rekonstrueerimisega, kus üksikleidude põhjal on võimalik teha joonistuste abil tõepäraseid oletusi tervikust. Eesti üks meisterlikumaid etnograafiliste-arheoloogiliste rõivaste ja tekstiilide joonistajaid ja rekonstrueerijaid kunstnik Melanie Kaarma (2004) peab eseme detailset läbijoonistamist kõige olulisemaks ja efektiivsemaks eseme tundmaõppimise viisiks, mis võimaldab aru saada nii selle kunagise valmistaja kui ka kasutaja mõttemaailmast (intervjuu M. Kaarmaga). Ka kunstnik Kaljo Põllu sõnul on etnograafiliste joonistuste näol tegemist omamoodi teadusliku uurimistööga, mille tulemused on esitatud kunstispetsiifilisi väljendusvahendeid kasutades (Põllu 2004).

Samast mõttekäigust lähtub ka ülalmainitud kunstiüliõpilaste etnograafiapraktikate pedagoogiline aspekt. Seega on joonistus ot- 


\section{Kadri Viires}

sekui kogemus ja tunnetusvahend, mis nõuab uuritava materjali süvenenud tundmaõppimist, mis pildistamise puhul võib tihtipeale jääda pealiskaudseks. Analoogiliselt fotodokumentalistikaga, milles David Levi Straussi (1988) järgi oluliseks viisiks illusiooni loomisel fotode objektiivsusest on nende esitlemine anonüümsetena, on ka kõigi dokumenteerivate joonistuste autorite allkirjad esitatud tagasihoidlikult. Toetudes ERMi etnograafiliste jooniste arhiivi registri andmetele, võib lisaks ülaltoodud tuntud nimedele tuua arvukalt näiteid kaasaegses eesti kunstis tegutsevate professionaalsete kunstnike hulgast, kes on olnud tegevad etnograafilise materjali dokumenteerimisel (Villu Järmut, Maria Kristina Ulas, Ly Lestberg, Loit ja Virge Jõekalda, Katrin Pere jpt), mistõttu kunsti ja dokumentalistikat ei saa käsitleda vastanditena, kus ühe olemuseks on "väljendus" (ekspressioon), teise omaks aga "jäljendus" (mimees). Pigem on tegemist informatsiooni tootmise erivormidega, kus sõnumi mahtu ja selle toimemehhanisme vaatajale määravad meediumispetsiifilised tegurid (Linnap 2000). Nii võiksid ka etnograafilistel joonistustel põhinevad näitused, mida on praktiseerinud nii ERM kui ka EKA, laiema publiku kõrval huvi pakkuda võrdselt nii etnoloogidele kui ka kunstiteadlastele.

\section{Arhiiviallikad}

EKA = Eesti Kunstiakadeemia: Meediateaduskonna graafilise disaini eriala arhiiv.

EKM G = Eesti Kunstimuuseumi graafikafond.

ERM EAV = Eesti Rahva Muuseumi etnograafiline arhiiv: Varia.

ERM EJ = Eesti Rahva Muuseumi etnograafiliste joonistuste kogu.

$\mathrm{SU}=$ Soome Rahvusarhiivi trükiste ja fotoarhiiv (National Board of Antiquities).

\section{Kirjandus}

Allikvee, Anu 1994. Estica baltisaksa kunstis 1800-1860 = Estica in der deutschbaltischen Kunst 1800-1860. Lõugas, Anne (koost). Neli baltisaksa kunstnikku: Carl Siegismund Walther, Friedrich Ludwig von Maydell, August Georg Wilhelm Pezold, Gustav Adolf Hippius: [Näitus, Tallinn-Jõhvi-Järvamaa, 1993]: Artiklite kogumik = Vier deutschbaltische Künstler . Tallinn : [Eesti Kunstimuuseum], lk 15-27. 


\section{Kadri Viires}

Astel, Eevi 1984. Eesti NSV Riikliku Kunstiinstituudi koostöö ENSV Riikliku Etnograafiamuuseumiga. Etnograafiamuuseumi aastaraamat = Ежегодник Этнографического музея XXXV. Tallinn: Valgus, lk 46-53.

Brotze, Joachim Christoph 1784. Sammlung Verschiedener Liefländischen Monumente, Prospecte, Münzen, Wappen. Originaal Riia Akadeemilises Raamatukogus (vt http://www.acadlib.lv/e/fondi/images/25.htm - 12. aprill 2005).

Georgi, Johann Gottlieb 1776a. Déscription de toutes les nations de l'Empire de Russie, où l'on expose leurs moeurs, réligions, usages, habitations, habillemens et autres particularités remarquables 1: Qui contient les nations d'origine finnoise. St. Petersbourg: Müller (vt ka http://www-gdz.sub.unigoettingen.de/cgi-bin/digbib.cgi?PPN33058913X - 12. aprill 2005).

Georgi, Johann Gottlieb 1776b. Déscription de toutes les nations de l'Empire de Russie, où l'on expose leurs moeurs, réligions, usages, habitations, habillemens et autres particularités remarquables 2: Seconde collection qui contient les nations tatares établies dans cet empire: Traduite de l'allemand. St. Petersbourg: Müller (vt ka http://www-gdz.sub.uni-goettingen.de/cgi-bin/ digbib.cgi?PPN33058927X - 12. aprill 2005).

Georgi, Johann Gottlieb 1777. Déscription de toutes les nations de l'Empire de Russie, où l'on expose leurs moeurs, réligions, usages, habitations, habillemens et autres particularités remarquables 3: Qui contenant les nations Samoyedes et Mandshoures, et les peuples les plus orientaux de la Sibirie. St. Petersbourg chez Charles Guillaume Müller (vt ka http://www-gdz.sub.unigoettingen.de/cgi-bin/digbib.cgi?PPN330589423 - 12. aprill 2005).

Gahlnbäck, Johannes 1910. Estnische Holzkrüge. Jahrbuch für Bildende Kunst in den Ostsee-provinzen 4. Riga: [s.n.], lk 122-135.

Heikel, Axel Olai 1909. Die Volkstrachten in den Ostseeprovinzen und in Setukesien. Kansatieteellisiä julkaisuja IV. Helsingfors : Société FinnoOugrienne.

Hupel, August Wilhelm 1777. Topographische Nachrichten von Lief- und Ehstland 2. Riga: [s.n.] 1777.

Hurt, Jakob 1989. Neli keelt "Vanast kandlest": [Setu rahvalaulud]. Tallinn: Kunst.

Lehtinen, Ildikó (toim) 1989. Museomiehen päiväkirjasta: A. O. Heikelin lehtikirjoituksia. [Helsinki]: Museovirasto.

Linnap, Peeter 2000. Dokumenteerimise sügavusest fotograafias ja filmis. Sirp 11 (2812), 24. märts.

Linnus, Jüri 1984. Üliõpilased etnograafilise materjali kogumisel. Etnograafiamuuseumi aastaraamat $=$ Ежегодник Этнографического музея XXXV. Tallinn: Valgus, lk 35-45. 


\section{Kadri Viires}

Manninen, Ilmari 1932. Eesti rahvariiete pildistused välismaa kirjanduses möödunud sajandeil. Eesti Rahva Muuseumi aastaraamat VII, 1931. Sihtasutis Eesti Rahva Muuseumi väljaanne 4. Tartu: Eesti Rahva Muuseum, lk 76-92.

Petina, Larissa 1998. Estica J. G. Georgi etnograafilises töös. Raamatukogu 6, lk 26-31.

Peterson, Aleksei 1984. Kolmveerand sajandit Eesti NSV Riiklikku Etnograafiamuuseumi. Etnograafiamuuseumi aastaraamat $=$ Ежегодник Этнографического музея XXXV. Tallinn: Valgus, lk 7-27.

Ribenis, Karin 1993. Jakob Hurda võõrkeelsed etnoloogilised artiklid. Keel ja Kirjandus 10, lk 605-617 \& 11, lk 665-672.

Sild, Hilja 1972. Kunstnike kaasabist Eesti Rahva Muuseumi rajamisel ja vanavarakogumisel. Tiik, Vaike (toim). Tartu Riikliku Kunstimuuseumi Almanahh. Tartu: Tartu Riiklik Kunstimuuseum, lk 60-68.

Sonesson, Göran. Chirography. The Internet Semiotics Encyclopaedia (http:// www.arthist.lu.se/kultsem/encyclo/chirography.html - 12. aprill 2005).

Strauss, David Levi 1988. Photography and Propaganda. Afterimage: The Journal of Media Arts and Cultural Criticism 15 (aprill) (sama ka Strauss, David Levi 2003. Photography and Propaganda. Strauss, David Levi. Between the eyes: Essays on photography and politics. New York: Aperture), lk 12-13.

Viidalepp, Richard 1938. Mida ja kuidas pildistada. Rahvapärimuste selgitaja 4. Tartu: Eesti Rahvaluule Arhiiv, lk 127-131.

Viires, Ants 1980. A. O. Heikel ja eesti teadus. Keel ja Kirjandus 6, lk 356-361.

Voolmaa, Aino 1959. Fr. R. Kreutzwaldi käsikiri Virumaa rahvarõivastest. Etnograafia Muиseumi aastaraamat = Ежегодник Этнографического музея XVI. Tallinn: Eesti Riiklik Kirjastus \& Eesti NSV Teaduste Akadeemia, lk 219-248.

Werner, Hans 1909. Runös Bauernkunst. Jahrbuch für Bildende Kunst in den Ostsee-provinzen 4. Riga: [s.n.], lk 7-24.

\section{Intervjuud}

Kaarma 2004 = Kadri Viirese intervjuu Melanie Kaarmaga. 6. märts.

Peterson 2004 = Kadri Viirese intervjuu Aleksei Petersoniga. 12. mai.

Põllu 2004 = Kadri Viirese intervjuu Kaljo Põlluga. 18. märts.

Tomberg 2004 = Kadri Viirese intervjuu Mall ja Bruno Tombergiga. 16. veebruar. 